\title{
Characteristics of Wolverine (Gulo gulo) dens in the lowland boreal forest of north-central Alberta
}

\author{
Michael E. Jokinen ${ }^{1, *}$, Shevenell M. WebB ${ }^{2}$, Douglas L. Manzer ${ }^{3}$, and Robert B. \\ ANDERSON $^{3}$
}

\begin{abstract}
${ }^{1}$ Alberta Conservation Association, 817-4th Avenue South, Lethbridge, Alberta T1J 0P6 Canada
${ }^{2}$ Maine Department of Inland Fisheries and Wildlife, 650 State Street, Bangor, Maine 04401 USA

${ }^{3}$ Alberta Conservation Association, P.O. Box 1139 Provincial Building, Blairmore, Alberta T0K 0E0 Canada

"Corresponding author: mike.jokinen@ab-conservation.com
\end{abstract}

Jokinen, M.E., S.M. Webb, D.L. Manzer, and R.B. Anderson. 2019. Characteristics of Wolverine (Gulo gulo) dens in the lowland boreal forest of north-central Alberta. Canadian Field-Naturalist 133(1): 1-15. https://doi.org/10.22621/cfn. v133i1.2083

\begin{abstract}
We investigated Wolverine (Gulo gulo) denning ecology in the boreal forest of northern Alberta. During winters 2015/2016 and 2016/2017, we used live traps to capture four female Wolverines and fitted them with global positioning system (GPS) collars programmed to take a location every two hours. We determined reproductive status at capture and GPS location data were used to identify den sites. One female denned in one of the two years, one female denned in two consecutive years, and two females did not den during the study. Seven of the eight Wolverine den sites were in mature or old Black Spruce (Picea mariana) stands, where dens consisted of a hollow, moss-covered mound originating from a partially uplifted root mass caused by a leaning or fallen tree. One den was located under decayed logging debris with an overstorey dominated by dense deciduous regeneration. Maximum snow depth recorded (December-March) at weather stations in the study area was $32-51 \mathrm{~cm}$. Spring snow coverage was scarce in our study area $(<1 \%)$ and always associated with ice cover on lakes and large ponds; mean distance from dens to nearest spring snow coverage was $15.19 \mathrm{~km}(\mathrm{SD}=2.73, n=8)$. Female Wolverines appear to be using locally-available denning structures in the lowland boreal forest, despite a lack of deep snow, persistent spring snow cover, or large boulders documented in other studies.
\end{abstract}

Key words: Alberta; boreal forest; den; lowlands; snow; Wolverine

\section{Introduction}

Wolverines (Gulo gulo) are well adapted to cold, snowy environments with their compact body, large paws, dense, frost-resistant fur, and capacity to store significant body fat (Banci 1994). Because Wolverines give birth in winter, females must find suitable den sites that are protected from predators, disturbance, cold temperatures, and melting spring snow (Magoun and Copeland 1998). Most verified Wolverine dens were under 1-5 m of snow (Pulliainen 1968; Magoun and Copeland 1998), suggesting that a deep snowpack offers important benefits throughout the denning season (Magoun and Copeland 1998). The majority of Wolverine den locations documented around the world ( $n=562$ dens) overlapped areas with persistent spring snow; a small subset of dens that were outside this mapped area of persistent spring snow cover (hereafter, the spring snow coverage) were visited and later confirmed to be snow dens (Copeland et al. 2010).

Deep snow and/or persistent spring snow cover has been associated with Wolverine dens throughout their distribution (Magoun and Copeland 1998; Copeland et al. 2010; May et al. 2012), but few dens have been described in low elevation, forested habitats. The majority of published information on Wolverine dens is from regions where deep snow was associated with steep, rugged terrain, and large boulders in Norway (May et al. 2012), woody debris and boulders in British Columbia (Krebs and Lewis 2000), long complex tunnels (Magoun and Copeland 1998) and drainage features in Alaska (Magoun et al. 2017), and fallen trees or boulders in Idaho (Copeland 1996; Magoun and Copeland 1998). A Wolverine denned under large boulders and downed trees in the low-elevation boreal forest of Ontario $(n=1$ den; Dawson et al. 2010) and females used boulder complexes in mature, mixed-coniferous boreal forests in Sweden $(n=49$ dens; Makkonen 2015). Given a lack of steep terrain and large boulders, a shallow snowpack, and relatively early spring snowmelt in the lowland boreal forest of northern Alberta (Webb et al. 2016), it was unclear what resident Wolverines were using for denning structures. 
Similar to Wolverines, American Black Bear (Ursus americanus) gives birth in winter and need to select den sites that will keep cubs dry, warm, and safe. In the northern boreal forests, most black bear dens are excavated, typically beneath ground level, under the roots of standing or partially blown-down trees, into hillsides, or into riverbanks (Fuller and Keith 1980; Klenner and Kroeker 1990). American Black Bear dens are typically in more upland forest stands, and peatland is avoided (Tietje and Ruff 1980). We hypothesized that in northern boreal landscapes, Wolverine dens located in upland habitat with mature forest cover and deeper snowpack would provide the best protection and insulation available, while more lowland, wet areas would not be used.

Although long-term fur harvests and images captured at camera traps suggest a reproducing population of Wolverines in northern Alberta (Webb et al. 2016), very little is known about denning ecology. Documenting den structures, snow conditions near dens, and duration of use, particularly in areas outside of the expected distribution of spring snow cover, could help clarify the relationship between Wolverines and snow and be useful information for timber harvest planning. Currently, Alberta's timber harvest guidelines list Wolverine dens under the "other species/sensitive site" section of the document, suggesting a forested buffer distance of 100 m (Alberta Agriculture and Forestry 2016); yet, there is no description of how to identify a potential Wolverine den. Our objectives were to: (1) document the general forest characteristics and specific structures associated with Wolverine den sites; (2) characterize snow, land cover, and industrial disturbance surrounding Wolverine den sites; and (3) summarize female Wolverine movements during the denning period (February-May).

\section{Methods}

The study area, roughly $4600 \mathrm{~km}^{2}$ in size, is located $\sim 500 \mathrm{~km}$ north of Edmonton and $100 \mathrm{~km}$ northeast of Red Earth Creek in north-central Alberta $\left(57^{\circ} \mathrm{N}, 114^{\circ} \mathrm{W}\right.$; Figure 1). The landscape is typical of Alberta's boreal region (Natural Regions Committee 2006), with a mosaic of aspen (Populus spp.)-dominated and aspen/White Spruce (Picea glauca (Moench) Voss) mixedwood forests in the uplands and extensive areas of Black Spruce (Picea mariana (Miller) Britton, Sterns \& Poggenburgh) treed fens and bogs in the surrounding wetlands. Approximately $42 \%$ of the study area is comprised of wetlands (fens, bogs, swamp, open water, and marsh), which were predominantly peatland forms (fens or bogs; $30 \%$ of the study area; AEP 2015). Mean elevation of overlapping townships within the study area is $616.98 \mathrm{~m}$ (SD
$=89.56, n=75$ townships) and ranged from 500 to $800 \mathrm{~m}$. Summers are short and cool, and winters are cold with snow typically covering the ground from November to mid-April. Mean August temperature in the study area was $13.68 \pm 1.86(\mathrm{SD}){ }^{\circ} \mathrm{C}$ (mean maximum August temperature $=18.2^{\circ} \mathrm{C}, n=5$ weather stations, 2003-2009; ACIS 2015).

The study area supported low numbers of Moose (Alces americanus) and White-tailed Deer (Odocoileus virginianus), and had a limited number of American Beaver (Castor canadensis); Gray Wolf (Canis lupus) occurred in small numbers when compared to other regions of the province. Caribou (Rangifer tarandus) are rare, but known to occur in the northern portion of the study area. American Black Bear, Canada Lynx (Lynx canadensis), American Marten (Martes americana), Fisher (Pekania pennanti), Ermine (Mustela erminea), Snowshoe Hare (Lepus americanus), Red Squirrel (Tamiasciurus hudsonicus), Spruce Grouse (Falcipennis canadensis), and Ruffed Grouse (Bonasa umbellus) were common.

The study area is remote and uninhabited, with little human activity due to limited access and extensive wetlands. The industrial footprint is small and comprised primarily of oil and gas development (e.g., all-season gravel roads, seismic lines from past exploration, and well-sites), with active forest harvesting occurring only in the extreme southern portion of the study area. Many of the seismic lines had experienced considerable regrowth of alder (Alnus spp.) and other shrubs. Active wells are visited on a regular basis by oil field staff, while unmaintained wells in the area (some of which were reclaimed and having shrub regrowth) receive little to no winter visitation based on our observations while working there. Gravel road and well-site density (including active and unmaintained wells) was $0.04 \mathrm{~km} / \mathrm{km}^{2}$ and 0.13 wells $/ \mathrm{km}^{2}$, respectively. Large wildfires were the primary disturbance in the area and approximately one-third of the study area had burned in the past 50 years (1961-2016).

We used baited run pole camera traps during winters $2014 / 2015$ ( $n=8$ run poles), 2015/2016 $(n=7$ run poles), and 2016/2017 ( $n=14$ run poles) to document the presence of individual Wolverines based on unique markings (Magoun et al. 2011). During winters 2015/2016 and 2016/2017 (November-March), we live-trapped Wolverines using 10 and 17 log box traps, respectively (Copeland et al. 1995). The run poles and live traps were spaced $\sim 5-10 \mathrm{~km}$ apart and were baited with beaver carcasses. Traps were outfitted with TT3 trap transmitters (Vectronic Aerospace, Berlin, Germany), which instantly sent an email message via satellite communication when a trap was triggered. On the advice of a wildlife veterinarian, 


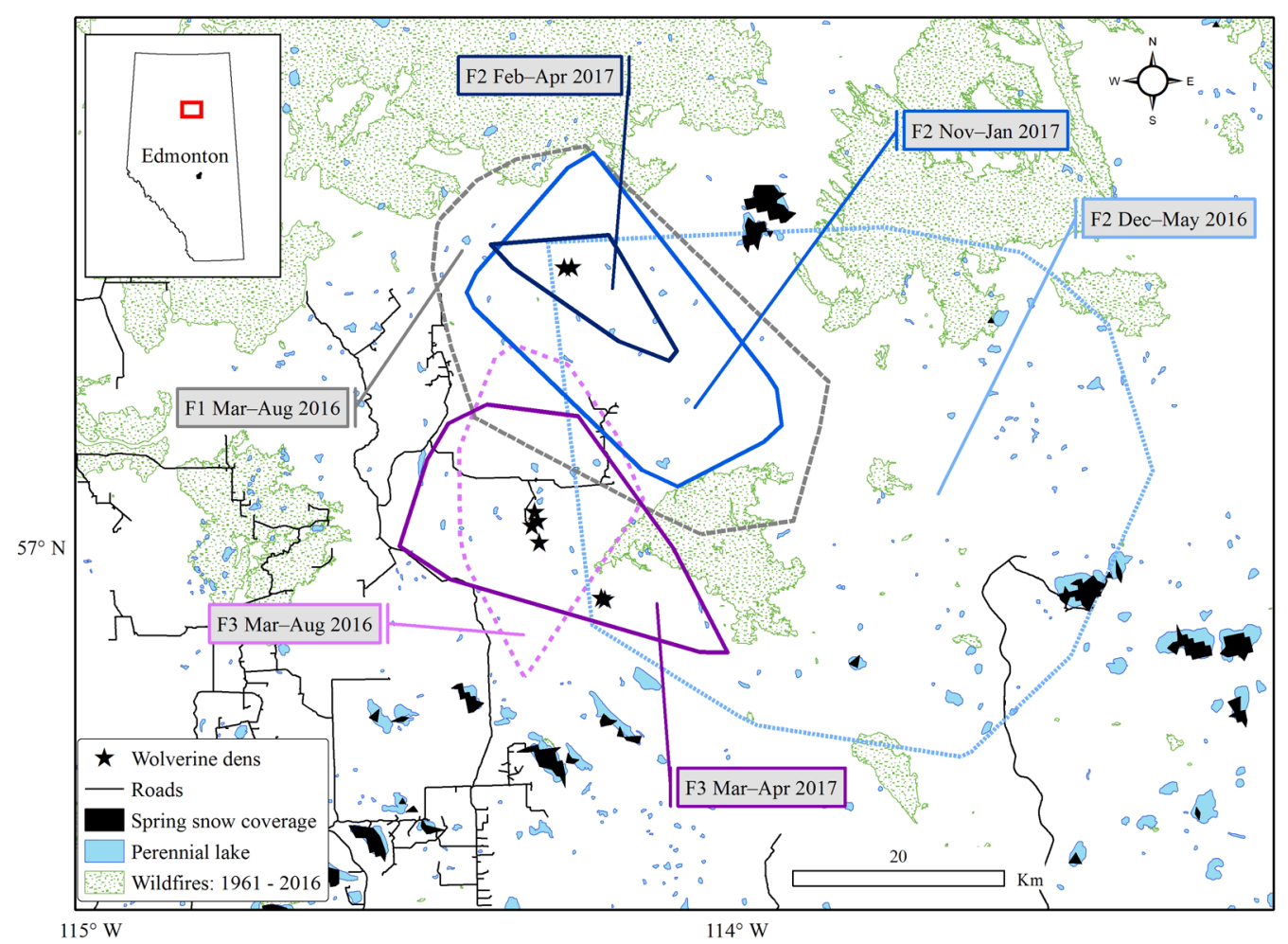

Figure 1. Wolverine (Gulo gulo) den locations (stars) and 100\% minimum convex polygon home ranges for three female Wolverines from 2015-2017 in north-central Alberta, Canada (inset).

Wolverines were immobilized using a jab stick (Dan-Inject, Borkop, Denmark) loaded with ketamine hydrochloride, $100 \mathrm{mg} / \mathrm{ml}$ (Ketalean; BimedaMTC Animal Health Inc., Cambridge, Ontario) and medetomidine hydrochloride, $1 \mathrm{mg} / \mathrm{ml}$ (Cepetor; Modern Veterinary Therapeutics, Miami, Florida, USA) at a dosage of $10.6-11.9 \mathrm{mg} / \mathrm{kg}$ and $0.1-0.12 \mathrm{mg} / \mathrm{kg}$, respectively. Wolverines were equipped with Tellus ultralight global positioning system (GPS) collars (Followit, Lindesberg, Sweden) that were programmed to take a location every two hours. Atipamezole hydrochloride $5 \mathrm{mg} / \mathrm{ml}$ (Revertor; Modern Veterinary Therapeutics) was hand injected to reverse the effects of the sedative. The animals were returned to the trap on a bed of spruce boughs until fully recovered and then released.

Collars uploaded data to a secure website via satellite communication, but there was typically a $2-3$ day time lag until locations became available. We visually inspected GPS collar data to identify potential reproductive den sites. Potential dens had a repeated pattern of collar locations within $100 \mathrm{~m}$ of each other and movements to/from a localized area, in addition to associations with long periods of GPS time-outs when we assumed females were underground in the den and satellites were not able to get a fix (February-April). The primary den was the first den we documented and secondary dens were subsequent dens used by female Wolverines (Makkonen 2015). We used the terms primary and secondary dens, similar to Makkonen (2015), because collaring sometimes occurred after kits were born; therefore, we could not be certain that the primary den was actually the natal den.

We used a geographic information system (ArcMap 10.4, Esri, California, USA) for all spatial calculations. We created a $5 \mathrm{~km}$ buffer around each den (estimated average female home range during the denning season; Makkonen 2015) and calculated density of gravel roads and well-sites (active and unmaintained). We measured distance of each den site to nearest gravel road and well-site rounded to the nearest whole number. We used multiple sources of data to characterize the study area climate. During winter 2016/2017, we established winter weather stations $(n=12)$ that were $10-20 \mathrm{~km}$ apart to measure local climate variables throughout the study area. Air temperature was recorded every hour using a Kimo KT50 compact temperature logger (Chevry-Cossigny, Seine-et-Marne, France). The temperature logger was not able to record temperatures below $-40^{\circ} \mathrm{C}$; how- 
ever, these were infrequent events. Snow depth was recorded by field staff on a weekly to biweekly basis using a stationary metal metre stick. Study weather stations were established in areas avoiding direct sunlight and unnatural tamping, drifting, or interception of snow. In addition to the winter weather stations we established, we summarized long-term (2005-2017) mean monthly temperature $\left({ }^{\circ} \mathrm{C}\right)$ at the nearest $(<20$ $\mathrm{km}$ ) five government-maintained weather stations surrounding the study area (i.e., Trout Mountain/ Peerless Lake, Chipewyan Lake, Loon River, Panny River, and Picadelly; ACIS 2015).

We used the spring snow coverage data from Copeland et al. (2010), which was estimated across the Wolverine's circumboreal range using MODIS, to classify $500 \times 500 \mathrm{~m}$ pixels over seven years $(2000-$ 2006). For each year, pixels received a one when the raster image was classified continuously as snow without any bare ground during the approximate end of the Wolverine denning period (24 April-15 May); the total number of years with continuous snow cover until mid-May was summed to get a value between one and seven for each pixel (Copeland et al. 2010). We created a $5 \mathrm{~km}$ buffer around each den site and calculated percent of area with spring snow coverage. We also used snow depth data from the Canadian Meteorological Centre (CMC) which was derived using interpolation models that incorporated actual daily snow measurements from weather stations, meteorological aviation reports, and special aviation reports from the World Meteorological Organization information system (Brasnett 1999; Brown and Brasnett 2010). We summarized long-term (19982014) mean monthly snow depths for CMC locations within our study area. We also inferred snow conditions using remote cameras and ground and aerial observations during a field visit in April 2017.

We created a $500 \mathrm{~m}$ buffer around each den site to characterize upland land cover (circa 2010; Castilla et al. 2014) and wetlands (circa 2015; AEP 2015). Land cover near dens included coniferous forest, broadleaf/deciduous forest, mixed forest, grassland, and shrubland. Wetland classes near dens included swamp, fen, and bog. We also overlapped den sites with the Derived Ecosite Phase, which is a representation of the vegetation, soil, and moisture conditions (wetland and upland; Figure 2) based on Alberta Vegetation Inventory and LiDAR (circa 2017; Alberta Agriculture and Forestry 2017).

We collected additional details related to forest structure and ecological classification at den sites during November and December 2017. Forest structure data were collected at five, $5.64 \mathrm{~m}$ radius plots. One plot was established at the den and the additional four plots were $30 \mathrm{~m}$ from the den in the four cardinal directions. Plot trees were identified to species and diameter at breast height was measured using a steel diameter tape for all trees $>5 \mathrm{~m}$ in height. Tree heights were measured with a clinometer and tree ages were determined using an increment borer, typically from the two trees having the largest diameter within each plot. We defined stand age class as young (20-49 years), mature (50-119 years), and old ( $\geq 120$ years), similar to Stelfox (1995). Each plot was classed to an ecosite phase, which is an Alberta-based field guide that subdivides forest types using site characteristics (moisture and nutrient regime), plant community type, soil type, and forest productivity information (Beckingham and Archibald 1996). Internal den dimensions were strictly based on a visual estimate as we did not want to enlarge the entrance and alter den structures.

Means \pm SD are reported for all parameters, unless otherwise indicated.

\section{Results}

The nature of the terrain (bogs and extensive wetlands), limited our ability to operate in the field beyond March. The transition from frozen to thawed ground occurred quickly (early April) and access to our remote field camp and the bulk of the study area was impractical. Therefore, we were unable to collect weather station data or monitor dens and litters during the denning months of April and May.

\section{Female Wolverines}

We captured four females (F1, F2, F3, and F4) over two winters (2015/2016 and 2016/2017). A year prior to our live captures, we identified F1 from camera images at run poles. F1's home range during the denning season (March-May) was similar $\left(859 \mathrm{~km}^{2}\right.$, $100 \%$ minimum convex polygon [MCP], $n=746$ locations) to her overall home range from 21 March to 2 August $2016\left(869 \mathrm{~km}^{2}, 100 \% \mathrm{MCP}, n=1046\right.$ locations; Figure 1). We had no evidence that she was lactating or denning.

We captured F2 during two winters. F2's home range 19 December 2015 to 15 May 2016 was 2254 $\mathrm{km}^{2}$ (100\% MCP, $n=1642$ locations; Figure 1), which was similar to her home range during the denning season that year (February-May; $2219 \mathrm{~km}^{2}$, 100\% MCP, $n=1163$ locations). She showed no sign of lactation or denning during this first winter and we suspect that she may have been a young female that ultimately took over the neighbouring F1's territory. We recaptured F2 on 30 November 2016 and again on 21 February 2017, and discovered she was lactating. Based on her subsequent movements and GPS timeouts, we believe she gave birth to her first litter of kits on or shortly after 22 February 2017, $\sim 9 \mathrm{~km}$ from where she was captured. Her collar largely timed-out 
a

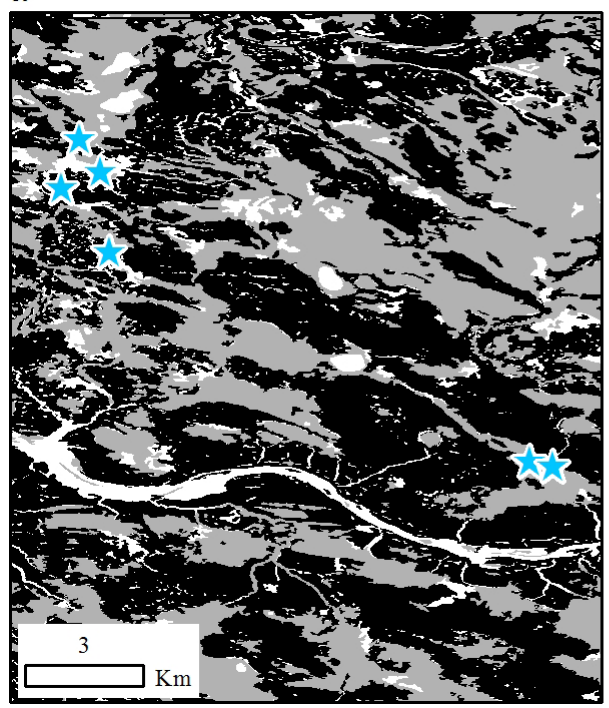

b

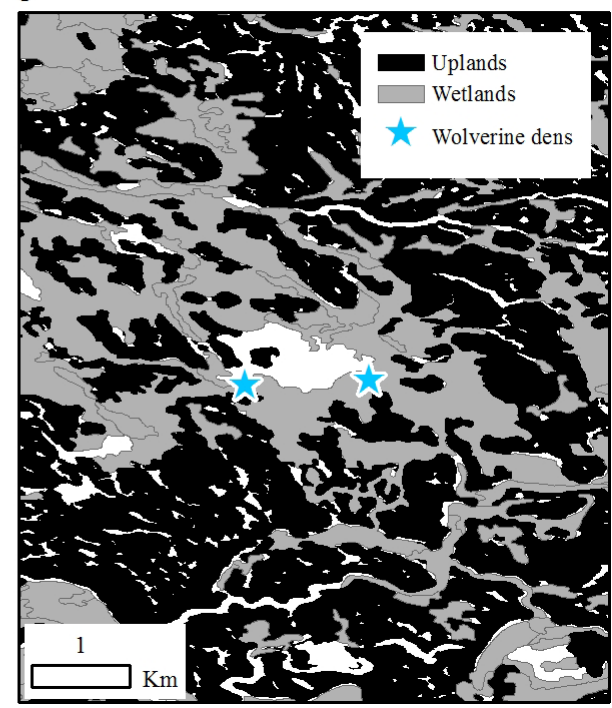

Figure 2. Upland and wetland matrix surrounding F3 (a) and F2 (b) den locations during 2016 and 2017 in north-central Alberta-only one den (F3 den 2, 2016) was within the upland category.

over a week-long period starting on 23 February and continued to time-out on a regular basis over the next several weeks. We monitored her movements until 9 April 2017 (premature collar failure) and documented her primary and secondary den (Figure 2b). F2 demonstrated strong fidelity to the primary den during the first four weeks (Table 1). The greatest movement she made was $\sim 12.5 \mathrm{~km}$ from her secondary den on 23 March 2017 to a location she had visited earlier in the winter, to feed on remnants of an American Black Bear hide. F2 used her primary den 22 February-13 March and secondary den until at least 26 March; the distance between the two dens was $\sim 700 \mathrm{~m}$. We suspect that F2 had another den (26 March-9 April), but we were not able to locate a third den when we searched a cluster of locations in late April. At a location where F2 had spent time (1-9 April), we did find three mounds of dead spruce limbs that had recently been broken off the lower section $(\sim 0.8 \mathrm{~m})$ of spruce trees. The breaking and piling of limbs appeared deliberate and bed-like, similar to the observation reported by a Finnish Wolverine hunter/trapper in
Pulliainen (1968). F2's home range from November to January was $484 \mathrm{~km}^{2}(100 \% \mathrm{MCP}, n=555$ locations), and $90 \mathrm{~km}^{2}(100 \% \mathrm{MCP}, n=309$ locations) while she was denning (February-April; Figure 1). F2's mean daily movements from February to April were $<5 \mathrm{~km}$, providing further evidence of raising young in 2017, especially when compared to the previous year when she did not raise young and her daily movements were $8-15 \mathrm{~km}$ during the same time period (Table 1).

We captured F3 during two winters. During the first winter, our staff set up trail cameras close to her secondary den and she moved immediately afterwards to a third den (Figure 2a); camera images documented F3 and her three kits leaving the den on the evening of 19 April 2016. Based on this experience, we chose not to visit female den sites during the denning period as we would not be able to determine whether the use of multiple dens was natural or influenced by researchers. We did receive collar location data for F3 after 4 May 2016, which was the last day she occupied den 4 . Over the next 27 days, F3 spent six days at one GPS cluster location and three

TABLE 1. Summary of daily movements (number of days, mean \pm SD km) made by female Wolverines (Gulo gulo) in each month of the denning season during 2016 and 2017 in north-central Alberta.

\begin{tabular}{|c|c|c|c|c|c|c|c|c|}
\hline Female_Year & & bruary & & March & & April & & May \\
\hline F1_2016 & - & - & 11 & $8.58 \pm 6.10$ & 30 & $11.18 \pm 8.80$ & 31 & $11.19 \pm 5.13$ \\
\hline F2_2016 & 29 & $8.22 \pm 7.12$ & 31 & $10.92 \pm 7.26$ & 30 & $15.19 \pm 8.16$ & 15 & $13.03 \pm 4.95$ \\
\hline F2_2017 & 7 & $2.67 \pm 4.22$ & 31 & $3.62 \pm 5.03$ & 8 & $4.58 \pm 3.31$ & - & - \\
\hline F3_2016 & - & - & 9 & $6.89 \pm 6.65$ & 30 & $10.23 \pm 8.50$ & 31 & $8.48 \pm 8.12$ \\
\hline F3 2017 & - & - & 10 & $9.11 \pm 5.64$ & 23 & $13.83 \pm 10.69$ & - & - \\
\hline
\end{tabular}


days at two additional locations but these remaining GPS clusters were not visited. F3's home range during the denning season (March-May) was $315 \mathrm{~km}^{2}$ (100\% MCP, $n=500$ locations), which was similar to her overall home range 22 March-16 August 2016 (338 km², 100\% MCP, $n=878$ locations; Figure 1). We recaptured F3 on 21 March 2017 and she was lactating; indicating that F3 had litters in two consecutive years. F3 used her primary den until 9 April and then occupied a secondary den $400 \mathrm{~m}$ away until at least 23 April (premature collar drop; Figure 2a). Her home range 21 March-27 April 2017 was 406 km² (100\% MCP, $n=193$ locations; Figure 1). Distance between F3's 2016 and 2017 primary dens was $\sim 8$ $\mathrm{km}$. Although home range size was similar between years, F3 moved further distances in 2017 compared to 2016 , and daily movements were much greater than the denning F2 (Table 1).

We captured F4 twice during March 2017, but she showed no signs of lactation in camera images or while we handled her 2 March and 26 March 2017. Her collar malfunctioned and we were not able to determine home range.

\section{Den descriptions}

Because we did not not disturb females while dens were in use and due to the challenges of working in the study area during April and May, most den sites were confirmed the following winter season. We found that using repeated patterns of GPS collar locations in combination with long periods of GPS time-outs to be an effective method of estimating den site locations. In 2016, F3's primary den was $20 \mathrm{~m}$ off our estimated GPS location and was confirmed with fresh Wolverine tracks leading in and out of the den. F3's secondary den in the regenerating cutblock was $10 \mathrm{~m}$ off our estimated location and was confirmed by very high frequency (VHF) signal and trail camera images. In 2017, F2's primary den was $10 \mathrm{~m}$ off our estimated location and was confirmed with packed snow/paths leading into the den. The remaining den locations that were visited the following season were an average of $21 \mathrm{~m}$ off the point derived from GPS clusters and time-outs. Alternative den structures in the immediate area of the estimated den locations were limited.

Seven of the eight Wolverine dens $(n=3$ primary, $n=5$ secondary) were in the hollow created by a partially uplifted root mass (i.e., root ball, root wad; hereafter uplifted root mass) of a leaning or fallen spruce tree. Seven of eight dens were located in mature (50119 years) or old ( $>120$ years) Black Spruce stands. Two of the seven dens were in mossy formations originating from an uplifted root mass where the trees had decayed, while the other dens were braced by the roots of intact leaning or fallen spruce trees. Root mass dens require little to no excavation by a Wolverine because a natural cavity is created when a thick moss blanket separates from the soil below as the shallow roots of a leaning or fallen tree upheave. Essentially, the lateral roots form the skeleton of the den, which supports a dense mat of soil and moss

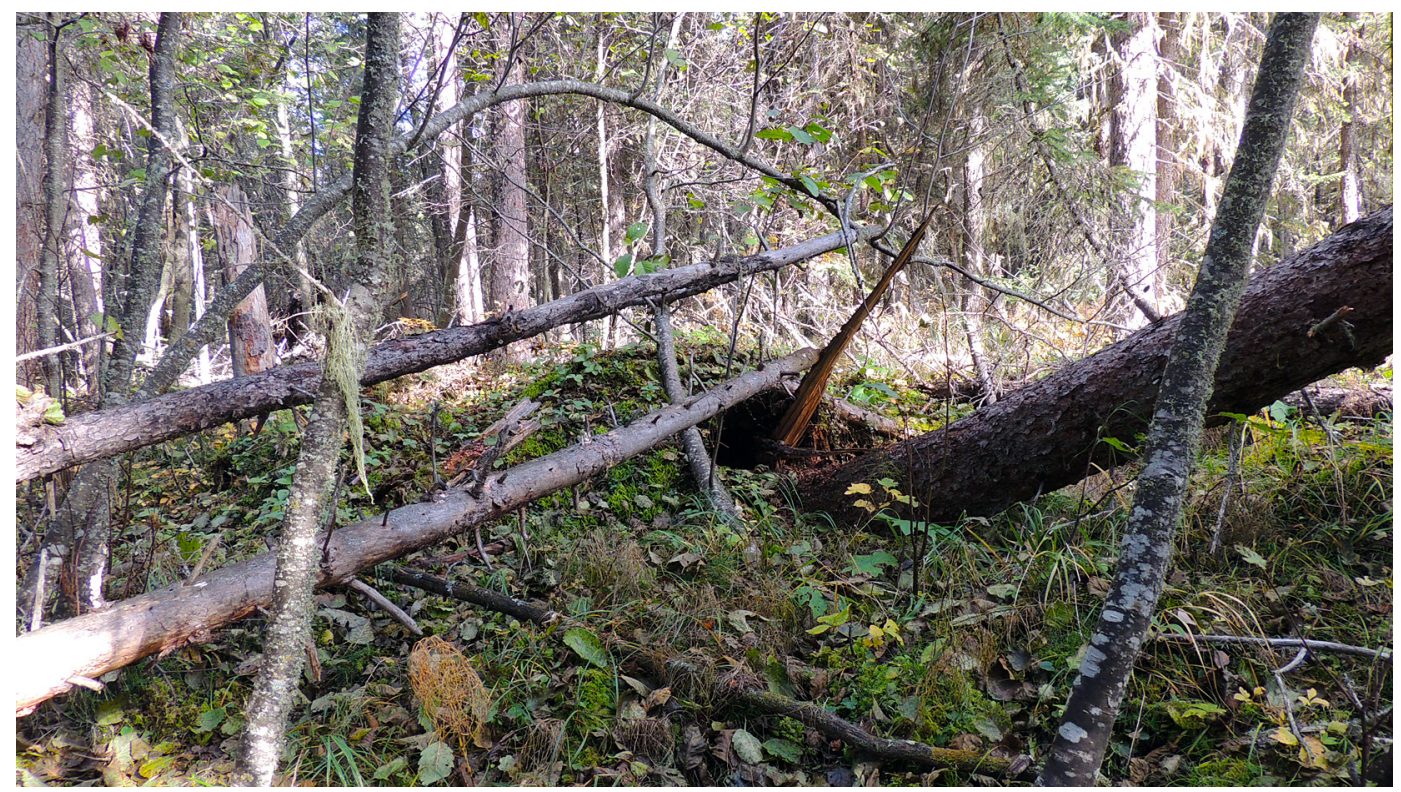

Figure 3. Wolverine (Gulo gulo) F3 2016 primary den was in a partially uplifted root mass of a leaning spruce tree. The den entrance is located along the upper side of the tree trunk in the centre of the den cavity. Photo: Michael Jokinen. 


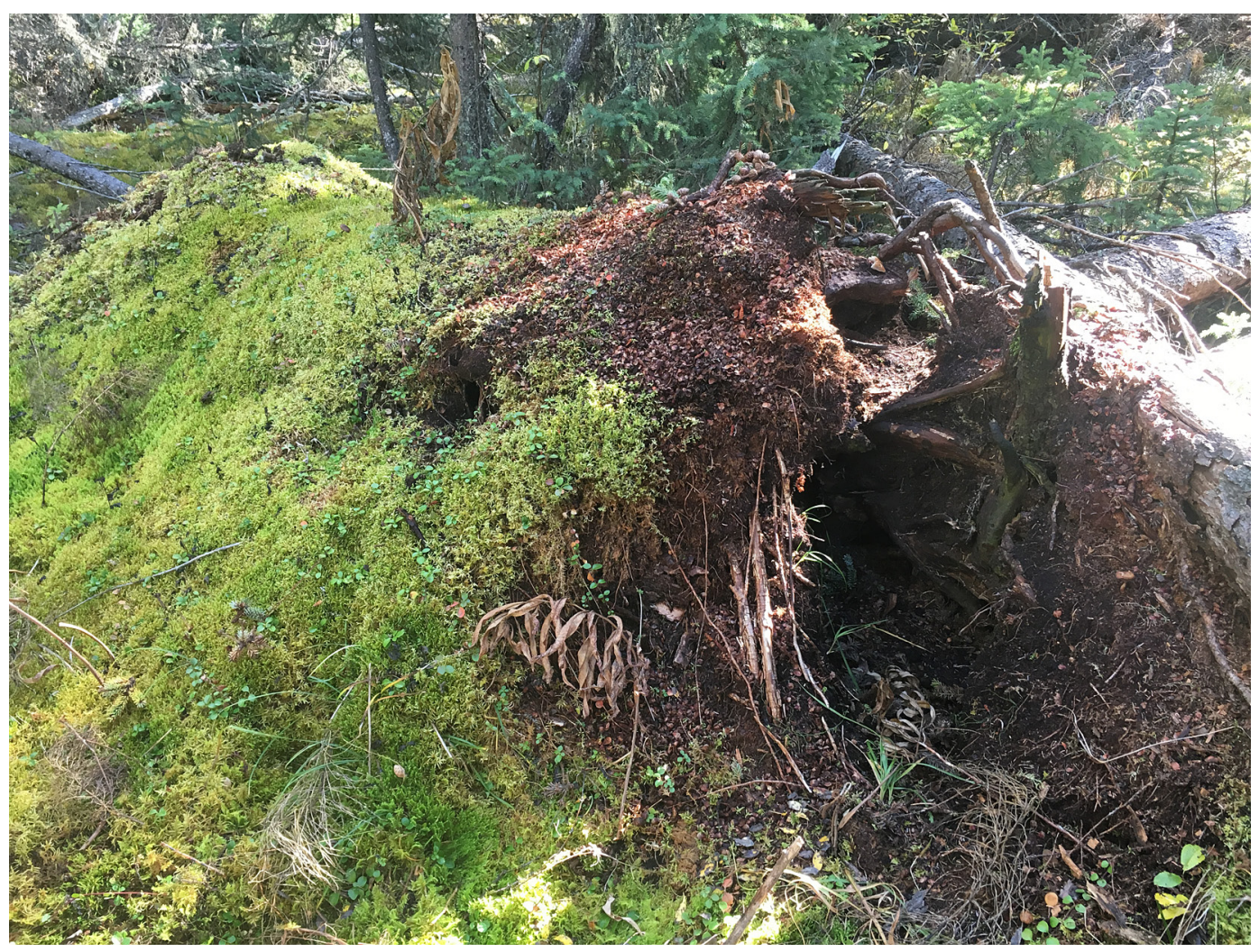

Figure 4. An example of a Wolverine (Gulo gulo) den underneath a partially uplifted root mass (F3 den 4, 2016) in the lowland boreal forest of north-central Alberta. The den entrance is located at the exposed root; the tree is lying on the ground (upper right) while the lateral roots opposite the entrance have curved, creating a natural cavity. Photo: Michael Jokinen.

creating the den walls (Figures 3 and 4). It is important to note that these root dens are not wind throw trees characterized by roots that have been pulled out of the ground and are left standing on end. Such trees also existed within the study area, but exposed standing roots do not create the mound and associated cavity that the Wolverines used in our study.

Estimated internal den dimensions were slightly variable in size, but den size was ultimately determined by the extent of the root heave $(\sim 1 \mathrm{~m} \times 1 \mathrm{~m})$. A soccer ball-sized opening $(\sim 30 \mathrm{~cm})$ often created the den entryway and most dens had alternate openings or potential escape routes in the walls. No material was brought into the dens by Wolverine, but spruce cone bracts often lined the floors. Cone seeds have been reported in Wolverine scat (Copeland 1996). However, we observed Red Squirrel caching of intact cones and cone feeding sites, where stripped cones lay beside piles of cone bracts in and around the den location. We did not observe animal remains or Wolverine scat inside or outside the dens. Snowshoe Hare sign was widespread around denning areas when we visited sites in November and December 2017.
One of the eight dens was located under decayed logging debris, which appeared to have been within or adjacent to a landing area used during previous forest harvesting activities. At the time of the observed den use, the overstorey was dominated by dense deciduous regeneration; the landing area and within-block roads were no longer apparent on the ground. We estimated that the cutblock was 27 years old based on tree aging and historical imagery from Google Earth (Google, Mountainview, California, USA), which suggested that the block was harvested in 1987. We could not determine the interior characteristics of this den without destroying the integrity of the structure.

\section{Ecosite classification at den sites}

Three primary and three secondary dens were revisited in November and December of 2017 to collect forest structure data. Two of F3's secondary dens from 2016 were not included in this den site forest assessment; however, they were similar in structure (uplifted root mass) and were dominated by old spruce forest based on observations made during a September 2016 visit. The study area is located 
within the transition zone of the Boreal Mixedwood and Boreal Highlands ecological areas (Beckingham and Archibald 1996). The Boreal Mixedwood and Highlands are ecologically similar, but the Highlands are slightly cooler $\left(1.7^{\circ} \mathrm{C}\right.$ cooler in summer $)$ and have higher precipitation in both summer and winter (28 $\mathrm{mm}$ higher in summer; winter comparison not available; Beckingham and Archibald 1996).

Based on the ecosite field guide of Beckingham and Archibald (1996), three of five dens (not including the den in the regenerating aspen stand) were an ecosite of Common Labrador Tea (Rhododendron groenlandicum (Oeder) Kron \& Judd)/horsetail (Equisetum spp.) in the Boreal Mixedwood ecological area and two were an ecosite of horsetail and White Spruce in the Boreal Highlands. Of the three Boreal Mixedwood den locations, all sample plots but one (treed poor fen) were identified to a Labrador Tea/ horsetail phase. The most common indicator species that we found at these ecosites included Black and White Spruce, alder, Labrador Tea, and horsetail. All but one sample plot (Labrador Tea-hygric Black Spruce-Jack Pine (Pinus banksiana Lambert)) at the two dens located in the Boreal Highland ecological area were identified to a horsetail and White Spruce ecosite phase. Indicator species at the two dens in this ecosite were similar to those found at Boreal Mixedwood ecosites. The conifer forest bordering the regenerating deciduous cutblock, in which F3's secondary den was located, appeared to consist primarily of a Labrador Tea/horsetail ecosite class of the Boreal Mixedwood. Table 2 lists the tree species, count and average tree diameter, height, and age measured at sample plots.

\section{Disturbance, land cover, and climate}

The elevation of dens ranged from 535 to $687 \mathrm{~m}$ above sea level $(601.5 \pm 52.6 \mathrm{~m}, n=8$; Table 3$)$. F2's dens were at similar elevations to the mean elevation of the surrounding township $(681 \mathrm{~m})$. F3 denned in the same township over two consecutive winters (township elevation $=557 \mathrm{~m}$ ). Dens were typically far from roads and wells (Table 3); however, that could simply reflect available habitat within the study area. Gravel road density within a $5 \mathrm{~km}$ buffer of each den was $0-0.18 \mathrm{~km} / \mathrm{km}^{2}\left(0.07 \pm 0.08 \mathrm{~km} / \mathrm{km}^{2}, n=8 \mathrm{dens}\right)$. Well density (active and unmaintained) within the 5 $\mathrm{km}$ buffer of each den was $0.04-0.08$ wells $/ \mathrm{km}^{2}(0.06$ \pm 0.02 wells $/ \mathrm{km}^{2}, n=8$ dens).

Conifer forest was the dominant land cover within the $5 \mathrm{~km}$ buffer for six of the eight dens (range: 50-100\%). One den was 54\% deciduous forest, $21 \%$ mixed forest, $21 \%$ conifer forest, and $3 \%$ shrub within this buffer area. The area surrounding the logging debris den had been classified as $65 \%$ shrub (primarily regenerating Populus spp. within a cutblock), 30\% conifer forest, 3\% grassland, and $2 \%$ deciduous forest; however, the regenerating cutblock had reached heights $>10 \mathrm{~m}$ by 2016 . There was a wide range in the amount of wetland within 500 $\mathrm{m}$ of each den (range: $10-74 \% ; 33.7 \pm 21.28 \%, n=$ 8 dens). The wettest den (74\% wetland) was classified as 53\% swamp, $18 \%$ fen, and 3\% bog within 500 m (F2's primary den). Six of the eight dens, however, had $10-35 \%$ wetland (mostly peatlands) within 500 m. Moreover, based on the Derived Ecosite Phase data, six of eight dens fell within the wetland category. This category is described as hydric/poor dominated by shrubby, treed bog vegetation (Alberta Agriculture and Forestry 2017).

Wolverine dens were 4-7 km to the nearest study weather station. Mean snow depths for each month were $32.4 \pm 12.6 \mathrm{~cm}$ in December, $37.6 \pm 11.1 \mathrm{~cm}$ in January, $41.4 \pm 14.7 \mathrm{~cm}$ in February, and $34.0 \pm 17.8$ cm in March ( $n=12$ stations; Table 4). Maximum snow depth recorded (December-March) at individual weather stations was $32-51 \mathrm{~cm}$. Hourly temperatures in the study area increased by the latter half of March (16-29 March, daily $\left.-3.6^{\circ} \mathrm{C}\right)$, as compared to the first half of the month $\left(1-15 \mathrm{March},-16.8^{\circ} \mathrm{C}\right)$. Mean monthly temperatures increased slightly with each month, while monthly ranges were highly variable: December $-14.4 \pm 6.8^{\circ} \mathrm{C}$ (range -36.0 to $2.9^{\circ} \mathrm{C}$ ),

TABLE 2. Forest stand structure (count, mean \pm SD) associated with Wolverine (Gulo gulo) dens $(n=6)$ during 2017 in the lowland boreal forest of north-central Alberta.

\begin{tabular}{lrrrrrrl}
\hline \hline Den & \multicolumn{2}{c}{ Tree DBH* $(\mathrm{cm})$} & \multicolumn{2}{c}{ Tree height $(\mathrm{m})$} & \multicolumn{2}{c}{ Tree age $(\mathrm{yrs})$} & \multicolumn{2}{l}{ Stem count } \\
\hline F3_1_2016 & 32 & $49.1 \pm 20.4$ & 10 & $17.6 \pm 4.7$ & 10 & $116.9 \pm 44.9$ & $23 \mathrm{Sb}, 8 \mathrm{Sw}, 1 \mathrm{Lt}$ \\
F3_2_2016 & 83 & $31.3 \pm 10.5$ & 10 & $14.5 \pm 3.5$ & 10 & $26.6 \pm 0.7$ & $19 \mathrm{~Pb}, 18 \mathrm{Aw}, 15 \mathrm{Sw}$ \\
F2_1_2017 & 113 & $23.4 \pm 12.2$ & 10 & $13.4 \pm 3.1$ & 10 & $70.5 \pm 22.7$ & $87 \mathrm{Sb}, 19 \mathrm{Sw}, 7 \mathrm{Lt}$ \\
F2_2_2017 & 84 & $30.6 \pm 15.9$ & 10 & $16.0 \pm 4.1$ & 10 & $85.8 \pm 28.7$ & $51 \mathrm{Sb}, 22 \mathrm{Sw}, 10 \mathrm{Lt}$ \\
F3_1_2017 & 70 & $42.8 \pm 25.7$ & 10 & $19.0 \pm 6.1$ & 10 & $121.9 \pm 37.5$ & $70 \mathrm{Sb}$ \\
F3_2_2017 & 40 & $57.6 \pm 25.5$ & 10 & $24.2 \pm 4.2$ & 10 & $114.6 \pm 18.3$ & $40 \mathrm{Sb}$ \\
\hline \hline
\end{tabular}

*Diameter at breast height (DBH).

${ }^{\dagger}$ Trees in plot $>5 \mathrm{~m}$ tall. Species: Trembling Aspen (Aw; Populus tremuloides Michaux), Balsam Poplar (Pb; Populus balsamifera L.), Black Spruce (Sb; Picea mariana (Miller) Britton, Sterns \& Poggenburgh), Tamarack (Lt; Larix laricina (Du Roi) K. Koch), and White Spruce (Sw; Picea glauca (Moench) Voss). 
TABLE 3. General summary of Wolverine (Gulo gulo) dens found in the lowland boreal forest during 2016 and 2017 in northcentral Alberta.

\begin{tabular}{|c|c|c|c|c|c|}
\hline Den & Date occupied & Elevation (m) & Entrance aspect & Nearest road $(\mathrm{km})$ & Nearest active wellsite $(\mathrm{km})$ \\
\hline F3_1_2016 & mid Feb-9 Apr* & 561 & $\mathrm{~S}$ & 2.0 & 2.0 \\
\hline F3_2_2016 & 10 Apr-19 Apr & 590 & $\mathrm{~S}$ & 0.4 & 0.4 \\
\hline F3_3_2016 & $20 \mathrm{Apr}-23 \mathrm{Apr}$ & 607 & $\mathrm{E}$ & 1.0 & 0.9 \\
\hline F3_4_2016 & 24 Apr-4 May & 615 & NW & 1.0 & 0.9 \\
\hline F2_1_2017 & $22 \mathrm{Feb}-13 \mathrm{Mar}$ & 673 & $\mathrm{~N}$ & 12.0 & 10.4 \\
\hline F2_2_2017 & $14 \mathrm{Mar}-26 \mathrm{Mar}$ & 687 & SE & 12.0 & 10.3 \\
\hline F2_3_2017 & 27 Mar-9 Apr ${ }^{\dagger \dagger}$ & - & - & - & - \\
\hline F3_1_2017 & mid-Feb-9 Apr* & 544 & W & 10.0 & 10.9 \\
\hline F3_2_2017 & $10 \mathrm{Apr}-23 \mathrm{Apr}^{\dagger}$ & 535 & $\mathrm{~S}$ & 10.0 & 11.0 \\
\hline
\end{tabular}

*F3 denning start date is approximate, as she was collared after kits were born in both instances.

$\dagger$ Collar failure or premature collar drop.

tUnconfirmed den location.

January $-14.0 \pm 10.2^{\circ} \mathrm{C}$ (range -40.0 to $10.5^{\circ} \mathrm{C}$ ), February $-12.7 \pm 10.1^{\circ} \mathrm{C}$ (range -40.0 to $19.2^{\circ} \mathrm{C}$ ), and March $-10.6 \pm 10.8^{\circ} \mathrm{C}$ (range -38.8 to $14.4^{\circ} \mathrm{C}$; Table 4). Mean monthly temperatures were similar between long-term data from nearby government stations (2005-2017) and monthly study station temperatures measured during winter 2016/2017 (Table 4).

CMC model grid points were $7-13 \mathrm{~km}$ from Wolverine den sites and indicated that snow depths are typically shallow in our study area (DecemberMarch, $21.66 \pm 1.77 \mathrm{~cm}$, range $19.74-25.03 \mathrm{~cm}, n=$ 10 stations; Brown and Brasnett 2010). Snow depths interpolated for points within the study area were slightly higher than mean monthly snow depth trends in the boreal forest of Alberta (February: $25.57 \mathrm{~cm}$, March: $24.24 \mathrm{~cm}, n=686$ stations; Webb et al. 2016).

Spring snow coverage (Copeland et al. 2010) was limited $(0.38 \%)$ and patchy (mean size $1.6 \pm 2.68$ $\mathrm{km}^{2}, n=11$ patches) in our study area. There were no instances of spring snow coverage predicted near Wolverine dens. Mean distance from dens to nearest spring snow coverage was $15.19 \pm 2.73 \mathrm{~km}(n=8)$. All patches of the spring snow coverage in the study area corresponded to lakes or large ponds that would be expected to retain at least some ice cover beyond when snow in the forest had melted.

We used trail cameras to document spring snow conditions for F3's primary and secondary dens in 2016. Her primary den was completely snow-covered on 30 March 2016 and 20 days later the snow had all melted. There was no snow cover surrounding the area of F3's secondary den on 19 April 2016. We visited the study area 25-27 April 2017 to retrieve dropped radio collars and observed patchy snow cover across the entire region, from the air (Figure 5) and on the ground. We used an Argo (New Hamburg, Ontario, Canada) to access the area of F2's primary den (2017) as she had not used this den for several weeks and patchy snow cover was encountered at the time. We did not locate F2's secondary den until November 2017 as we were not confident that she was finished using the den during our April visit. We flew over (Figure 5) and hiked within 1 km of F3's 2017 dens while retrieving her dropped radio collar and encountered sparse snow cover throughout the area.

\section{Discussion}

Wolverine pregnancy is largely dependent on body

TABLE 4. Mean temperature and snow depths ( \pm SD) recorded at study weather stations (2017), government weather stations (2015-2017), and Canadian Meteorological Centre (CMC) locations (1998-2014) during December-May in northcentral Alberta.

\begin{tabular}{|c|c|c|c|c|c|c|}
\hline Weather station & December & January & February & March & April & May \\
\hline \multicolumn{7}{|l|}{ Study stations } \\
\hline $\begin{array}{l}\text { Temperature }\left({ }^{\circ} \mathrm{C}\right) \\
n=12\end{array}$ & $-14.4 \pm 6.8$ & $-14.0 \pm 10.2$ & $-12.7 \pm 10.1$ & $-10.6 \pm 10.8$ & 一 & - \\
\hline $\begin{array}{l}\text { Snow depth }(\mathrm{cm}) \\
n=12\end{array}$ & $32.4 \pm 12.6$ & $37.6 \pm 11.1$ & $41.4 \pm 14.7$ & $34.0 \pm 17.8$ & 一 & - \\
\hline \multicolumn{7}{|l|}{$\begin{array}{l}\text { Government stations } \\
\text { and CMC estimates }\end{array}$} \\
\hline $\begin{array}{l}\text { Temperature }\left({ }^{\circ} \mathrm{C}\right) \\
n=5\end{array}$ & $-15.8 \pm 0.7$ & $-18.1 \pm 0.8$ & $-13.9 \pm 0.8$ & $-7.5 \pm 0.6$ & $2.5 \pm 0.2$ & $8.7 \pm 0.2$ \\
\hline $\begin{array}{l}\text { Snow depth }(\mathrm{cm}) \\
n=10\end{array}$ & $14.7 \pm 1.2$ & $21.3 \pm 1.5$ & $26.5 \pm 2.1$ & $24.2 \pm 2.6$ & $5.6 \pm 1.2$ & $0.2 \pm 0.1$ \\
\hline
\end{tabular}




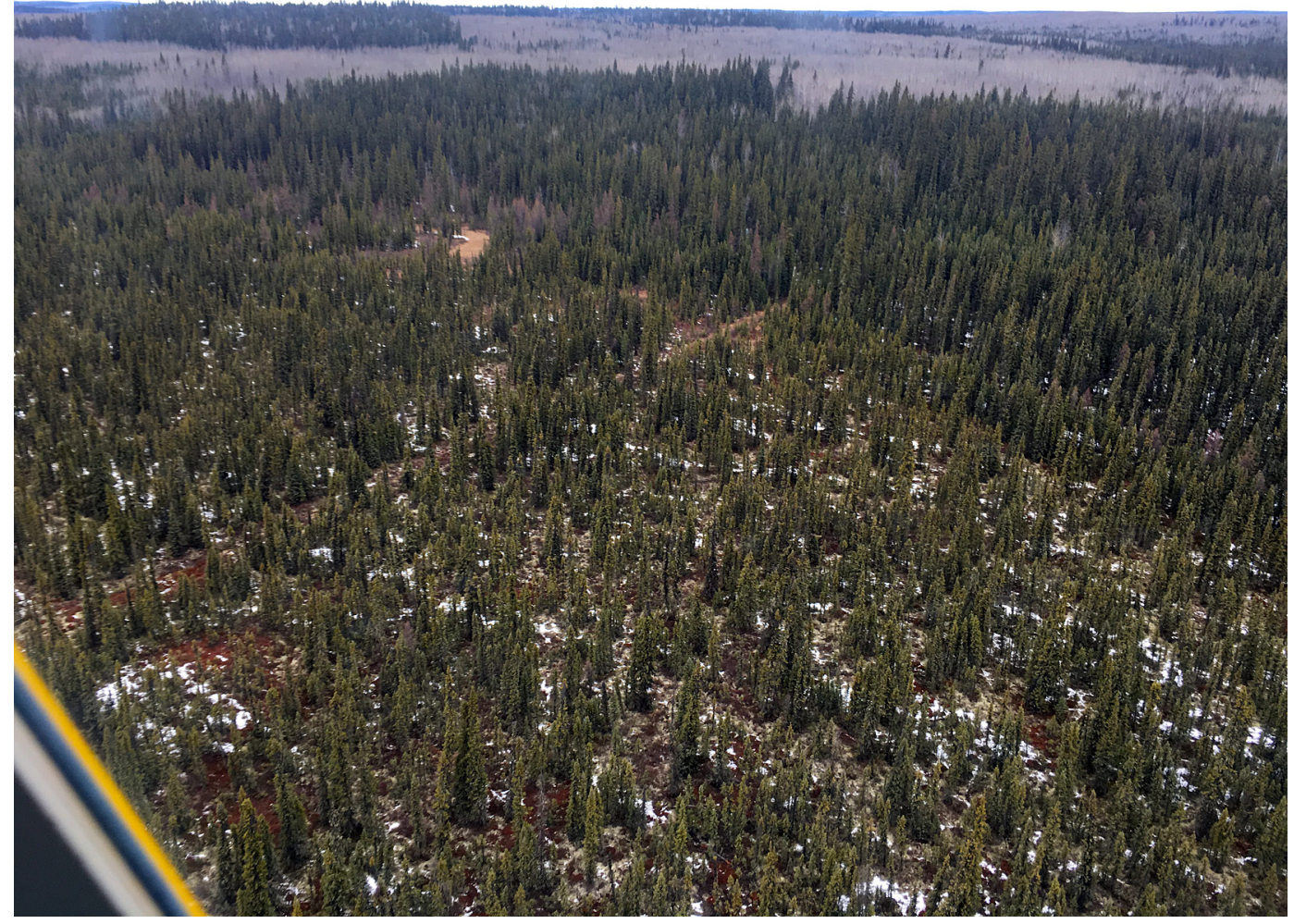

Figure 5. Snow cover near Wolverine (Gulo gulo) F3 primary den on 27 April 2017 in north-central Alberta. Photo: Michael Jokinen.

condition and winter food availability (Persson 2005), because of delayed implantation (Banci 1994). It has been hypothesized that dens that provide females and their offspring with secure shelter from disturbance (e.g., predation, weather, people), thermal insulation (Magoun and Copeland 1998), and access to adequate food resources (Inman et al. 2012) may be more likely to produce successful litters. Nearly all documented Wolverine dens in the world have been associated with deep snow (Magoun and Copeland 1998) and/or persistent spring snow cover (Copeland et al. 2010); however, Wolverines have not been studied equally across their range (Banci 1994), particularly in North America. We recognize that our sample size of denning females was small and that reproductive success was not measured for those females; however, our study detected a Wolverine denning strategy that is largely undescribed. We documented Wolverine dens in low elevation forests lacking boulders and deep or persistent spring snow, where a core, resident population has supported Wolverine harvests for over 30 years (Webb et al. 2016). Our results provide further evidence that Wolverines are adapted to exploiting cold, low productivity environments, but females appear to be selecting denning habitat that differs from what we hypothesized and what has been reported elsewhere.

In addition to shallow snow cover, our study area had other unique differences from other Wolverine studies. Ungulates can be important in the diet of female Wolverines (Banci 1994; Inman et al. 2012), yet ungulates were in low abundance in our study area and in much of the boreal forest, where smaller prey including American Beaver, Snowshoe Hare, and grouse are more common. Female Wolverine in northern British Columbia were positively associated with rugged terrain in alpine environments, where Hoary Marmot (Marmota caligata) and Columbian Ground Squirrels (Urocitellus columbianus) were common (Krebs et al. 2007). Although the Omineca region of British Columbia is at similar latitude, our study area does not support this prey or terrain selection. Not unlike the difference between northern mountain and boreal ecotypes of Woodland Caribou (Wood and Terry 1999; ASRD \& ACA 2010), Wolverines in our study area must meet their needs in a very different environment. Although we lacked data on winter food availability, we documented one female that 
denned in two consecutive years, with three kits confirmed to be alive at $\sim 4-6$ weeks of age in the first year. Snowshoe Hare and Canada Lynx sign was common during our study. Based on Canada Lynx harvests, Snowshoe Hare cycle peaks in Alberta have occurred around 1980, 1990, 2000, and 2010 (Webb et al. 2013). Snowshoe Hare numbers were increasing during our study (N. Kimmy pers. comm. 30 January 2019). The habitat within our study area was highly mosaic, likely a result of frequent fires and abundant wetlands. Female Wolverines may rely on hunting small prey, such as Snowshoe Hare (Banci 1994; Scrafford and Boyce 2015), and this varied landscape may provide hares the forage, concealment, and thermal cover to persist in relatively good numbers throughout the various habitat types (Hodges 2000; Gigliotti et al. 2018). Krebs et al. (2018) state that the Snowshoe Hare is one of the few prey species available to predators during the winter in the boreal forest. All avian and mammalian predators in the boreal forest eat Snowshoe Hare (Krebs et al. 2018). Wolverine and Canada Lynx harvest data have shown that a pattern may exist between Wolverine harvest and the Snowshoe Hare cycle (Webb et al. 2013; Boonstra et al. 2018). By denning within mature conifer, female Wolverines in the boreal forest may have access to a prey source in close proximity.

Inman et al. (2012) suggest there may be a connection between food storage, persistent spring snow cover, and Wolverine denning requirements. If deep snow may provide an opportunity for food caching in other settings, it begs the question: How are Wolverines meeting this need in a landscape where snow is far less abundant? We do not have the data required to answer this question, but local knowledge may have provided a hypothesis worth testing with future studies. On three independent occasions, trappers in our study area observed a Wolverine having depredated a harvested Canada Lynx from a trap, bringing it into an adjacent peatland area, and caching it. In each case, the trapper reported seeing that the Wolverine had dug through the snow and down into the organic peat layer, then buried the carcass up to $45 \mathrm{~cm}$ below the surface with a mixture of snow, moss, and other vegetation. In one case, the trapper reported that the Wolverine had urinated on top of the location before leaving; another reported finding it very challenging to dig into the cache as the infill had frozen solid. Scrafford and Boyce (2015) also documented Wolverines caching in bogs in northern Alberta. We observed instances where it appeared that a wolverine had returned to a peatland cache and excavated and fed on food remnants (M.E.J. unpubl. data). Burying foods into bogs may help preserve excess food for later use (Verhoeven and Liefveld
1997; Moldowan and Kitching 2016) or hinder competitors from locating it. Future research into boreal Wolverine ecology should seek to test this hypothesis.

Wolverine dens have been documented under wind-drifted snow, large boulders, and trees in areas with deep snow (Magoun and Copeland 1998; Krebs and Lewis 2000; Copeland et al. 2010; May et al. 2012; Makkonen 2015; Magoun et al. 2017), but these features are lacking in the boreal forests of northern Alberta. Instead, most dens in our study $(n=7)$ were under partially uplifted root masses of leaning or fallen trees in older spruce forests, while one den was under decayed logging debris in an 30 year old regenerating deciduous forest. We realize that our sample size of two denning females and their choice of denning structure could be a result of individual preference. However, Scrafford and Boyce (2015) also found Wolverines denning in an uplifted root mass and timber slash pile near Rainbow Lake in northwestern Alberta. Approximately $42 \%$ of our study area is comprised of various wetland forms, including a majority made up by peatlands, with a mean elevation of $600 \mathrm{~m}$. Makkonen (2015) notes that no dens were found in peat bogs, despite their abundance on the boreal landscape in Sweden, but Wolverines had access to and used large boulders at higher elevations for denning. Pulliainen (1968) found that half of the Wolverine dens in the boreal forest of Finland were associated with standing or fallen spruce trees; however, the dens and tunnels were established under the length of a fallen tree and were always under deep snow cover $(>1 \mathrm{~m})$. In contrast, maximum snow depth in our study rarely exceeded half a metre and was meaningfully absent for the final third of the denning season.

American Black Bears use a variety of den structures across their range, but adequate thermal cover is critical for successful reproduction in northern climates. The most common black bear den was under the roots or stumps of standing or partially blown down trees in the boreal forest of Ontario (Kolenosky and Strathearn 1987), Manitoba (Klenner 1982), and Alberta (Tietje and Ruff 1980), and the den chamber was similar in size to what we measured inside Wolverine dens $\left(\sim 1 \mathrm{~m}^{3}\right)$. Contrary to black bear dens, however, the Wolverine dens we investigated were not deliberately lined with other materials (e.g., grass, moss, leaves, twigs; Klenner 1982). Instead, most of the Wolverine dens had cone bracts inside that had been discarded by feeding Red Squirrels. Squirrel middens have also been associated with marten den sites (Ruggiero et al. 1998) and Western Toad (Anaxyrus boreas) hibernation sites (Browne and Paszkowski 2010), where it has been suggested that they may provide some thermal benefit. Marten 
will utilize root masses of fallen trees for winter rest sites (Gilbert et al. 1997) and den sites can occur underground (Bull and Heater 2000). Browne and Paszkowski (2010) note that Western Toad hibernation sites in north-central Alberta were also located within peat hummocks and decayed root channels.

Mosses are the prevalent ground cover in the wetland environments of the boreal forest. Instead of deep snow $(>1 \mathrm{~m})$ providing thermal protection (Magoun and Copeland 1998), it is possible that the thick moss layer insulates Wolverine dens from cold temperatures and excess moisture. Snow accumulation in our study area averages only $30-40 \mathrm{~cm}$, but when combined with the thick, mossy root layer, these den structures may provide adequate thermal insulation. Moss was traditionally used by Laplanders and other circumpolar people for bedding and insulation in both dwellings and clothing (Kimmerer 2003). Various species of moss have been shown to have thermal properties that insulate and limit the fluctuation of soil temperature and moisture (Soudzilovskaia et al. 2013). Marchand (2014) suggests that under $40-50 \mathrm{~cm}$ of snow, air temperature fluctuations have little influence on subnivean conditions. We suspect that typical late winter snow depth in our study area, in combination with the layer of moss, may also approximate those conditions.

The ecosites in which our dens were located are naturally wet and are rated as having high excess moisture (Beckingham and Archibald 1996). Even though these ecosites have elevated water tables near the ground surface, the den cavities are shallow and not far below the mossy forest floor. Because snow cover is relatively light and the den floor close to ground level, the probability of the den flooding during spring melt would be low.

Wind-throw hazard (i.e., potential for trees to become partially or completely uprooted) is rated as medium-high/high for the ecosites where dens were found in our study area (Beckingham and Archibald 1996). The potential for ready-to-move-in den structures in this forest type is therefore greater. The lateral roots and soil lining create a barrier, although the walls are relatively thin $(\sim 15-30 \mathrm{~cm})$ and appear fragile even when snow-covered. The root mass walls provide limited protective shielding from potential danger, so females may be more susceptible to disturbance. However, this did not seem to result in them moving denning sites more frequently, as other studies documented similar number of dens per female as we did (Magoun and Copeland 1998). The proximity of a den structure to potential human disturbance is likely important (Banci 1994). Our study area was remote and most dens were located far from roads and trails, where encounters with people would be rare. In addition to potential direct disturbance at the den, Scrafford et al. (2018) suggested that roads may negatively influence Wolverines by altering both habitat use and movement rates through habitat near roads. However, the density of roads near den sites in our study was an order of magnitude less than that of Wolverine home ranges in their study, suggesting that these females may be less impacted by roads. In addition, ungulates were not abundant in our study area, so wolf numbers were not high. This may lessen the need to have a secure den structure as would be provided by a snow cave or large boulders.

Forest companies seeking to provide long term Wolverine denning habitat within low elevation boreal forests have been operating with a paucity of information, trying to determine how to apply what is known about dens from a mountain environment to one largely devoid of boulders and a deep, persistent snow pack. Although our observations are limited, these females, and those of the Scrafford and Boyce (2015) study, provide a glimpse into the unique denning ecology of boreal Wolverines. Until more detailed information can be obtained, forest companies should retain mature representative samples of high-wind-throw-risk ecosites within their planning area. In some cases, forest harvesting may have the potential to create future suitable denning habitat when structure is left behind (e.g., brush piles, log landings). Although the availability of partially wind thrown trees may not be limiting on the boreal landscape, their suitability for den sites may be influenced by the degree of disturbance in the surrounding area.

In the absence of deep snowpack, Wolverines in our study area have found a way to persist in the lowland boreal forest. Our small sample size limits our ability to draw robust conclusions. As such, our observations and speculation about potential ecological processes should be viewed as the basis for hypotheses that can be tested with further study. In a landscape lacking deep snowpack and large boulders, we speculate that Wolverines are able to meet their needs through locally available features such as the cavity created by a partially uplifted root mass, the thermal properties of thick moss, and the caching opportunities provided by deep peat accumulations. Wolverines are resourceful and may be more flexible in their denning requirements than documented by studies in other landscapes.

\section{Author Contributions}

Writing - Original Draft: M.J., S.W., and R.A.; Writing — Review \& Editing: M.J., S.W., and R.A.; Conceptualization: M.J., S.W., D.M., and R.A.; Investigation: M.J., S.W., and R.A.; Methodology: M.J., 
S.W., and R.A.; Formal Analysis: M.J., S.W., and R.A.; Funding Acquisition: R.A., D.M., and S.W.

\section{Acknowledgements}

A special thank you goes to Neil Kimmy and Bill Abercrombie (Alberta Trappers' Association members) for assisting with project establishment. A huge thank you goes to the Kimmy family for providing field accommodation and field support, while Duncan Abercrombie and Dan Mclean of Animal Damage Control contributed with their time and expertise in the field. John Hallett, Registered Professional Forester, Alberta Conservation Association (ACA), made a special contribution by providing forestry and ecosite classification expertise and Corey Rasmussen, ACA, was an essential member of the immobilization crew. A special thank you to all ACA staff (there were many) who participated in the field. Matt Scrafford, University of Alberta, and staff at Animal Damage Control, contributed by establishing the first Wolverine live traps within the study area. Mark Boyce, University of Alberta, who has been a collaborator on much of our Wolverine work in the province, loaned us equipment. We thank Dr. Michelle Oakley, Doctor of Veterinary Medicine (DVM), and Dr. Mark Johnson, DVM, for their immobilization training and guidance and Dr. Glenn Meyers, DVM, for providing immobilization agents. We also appreciate the spring snow coverage GIS data from Jeffrey Copeland. This study was supported by Alberta Conservation Association, Alberta Environment and Parks, Alberta Trappers' Association, Alberta-Pacific Forest Industries Inc., Crowsnest Conservation Society, Daishowa-Marubeni International Ltd., McGill University, Roadrunner Leasing and Sales Ltd., Shell FuellingChange, TD Friends of the Environment, and the University of Alberta. Capture and handling protocols and run pole camera traps were approved by the following Government of Alberta Research Permit and Collection Licences (\#56202, 56203, $56900,56901,57157,57158,58403,58404)$.

\section{Literature Cited}

ACIS (Alberta Agriculture and Forestry, AgroClimatic Information Service). 2015. Weather stations data viewer. Accessed 20 January 2019. http://agriculture.alberta. ca/acis/.

AEP (Alberta Environment and Parks). 2015. Alberta Wetland Classification System. Accessed 1 February 2018. https:/geodiscover.alberta.ca/geoportal/catalog/ search/resource/details.page?uuid $=\{$ A73F5AE1-46774731-B3F6-700743A96C97\}.

Alberta Agriculture and Forestry. 2016. Alberta timber harvest planning and operating ground rules framework for renewal. Alberta Forest Management Branch. Accessed 29 January 2018. https://wwwl.agric.gov.ab.ca/ \$department/deptdocs.nsf/all/formain 15749/\$FILE/
TimberHarvestPlanning-OperatingGroundRules Framework-Dec2016.pdf.

Alberta Agriculture and Forestry. 2017. Derived Ecosite Phase Version 1. Accessed 1 March 2019. https://open. alberta.ca/opendata/derived-ecosite-phase\#summary.

ASRD \& ACA (Alberta Sustainable Resource Development and Alberta Conservation Association). 2010. Status of the Woodland Caribou (Rangifer tarandus caribou) in Alberta: Update 2010. Alberta Sustainable Resource Development. Wildlife Status Report No. 30 (Update 2010). Edmonton, Alberta, Canada. Accessed 1 March 2019. https://open.alberta.ca/dataset/05cde28e5fbf-4906-9adf-eefbb26a2d1e/resource/9dd983040ddc-40cb-b94c-44158ca4bad8/download/47826812010-status-woodland-caribou-alberta-update-2010. pdf.

Banci, V. 1994. Chapter 5: Wolverine. Pages 99-127 in The Scientific Basis for Conserving Forest Carnivores: American Marten, Fisher, Lynx, and Wolverine in the Western United States. Edited by L.F. Ruggiero, K.B. Aubry, S.W. Buskirk, J.L. Lyon, and W.J. Zielinski. U.S. Department of Agriculture, Forest Service, Rocky Mountain Forest and Range Experiment Station. Fort Collins, Colorado, USA.

Beckingham, J.D., and J.H. Archibald. 1996. Field Guide to Ecosites of Northern Alberta. Natural Resources Canada, Canadian Forest Service, Northwest Region Forestry Centre, Edmonton, Alberta, Canada.

Boonstra, R., S. Boutin, T.S. Jung, C.J. Krebs, and S. Taylor. 2018. Impact of rewilding, species introductions and climate change on the structure and function of the Yukon boreal forest ecosystem. Integrative Zoology 13: 123-138. https://doi.org/10.1111/1749-4877.12288

Brasnett, B. 1999. A global analysis of snow depth for numerical weather prediction. Journal of Applied Meteorology 38: 726-740. https://doi.org/10.1175/1520-04 50(1999)038<0726:agaosd $>2.0 . c 0 ; 2$

Brown, R.D., and B. Brasnett. 2010. Canadian Meteorological Centre (CMC) daily snow depth analysis data. Environment Canada, National Snow and Ice Data Centre, Boulder, Colorado, USA. Accessed 1 February 2018. https://nsidc.org/data/NSIDC-0447.

Browne, C.L., and C.A. Paszkowski. 2010. Hibernation sites of Western Toads (Anaxyrus boreas): characterization and management implications. Herpetological Conservation and Biology 5: 49-63.

Bull, E.L., and T.W. Heater. 2000. Resting and denning sites of American martens in Northeastern Oregon. Northwest Science 74: 179-185.

Castilla, G., J. Hird, R.J. Hall, J. Schieck, and G.J. McDermid. 2014. Completion and updating of a landsat-based land cover polygon layer for Alberta, Canada. Canadian Journal of Remote Sensing 40: 92-109. https://doi.org/10.1080/07038992.2014.933073

Copeland, J.P. 1996. Biology of the wolverine in central Idaho. M.Sc. thesis, University of Idaho, Moscow, Idaho, USA.

Copeland, J.P., E. Cesar, J.M. Peek, C.E. Harris, C.D. Long, and D.L. Hunter. 1995. A live trap for wolverine and other forest carnivores. Wildlife Society Bulletin 23: $535-538$. 
Copeland, J.P., K.S. McKelvey, K.B. Aubry, A. Landa, J. Persson, R.M. Inman, J. Krebs, E. Lofroth, H. Golden, J.R. Squires, A. Magoun, M.K. Schwartz, J. Wilmot, C.L. Copeland, R.E. Yates, I. Kojola, and R. May. 2010. The bioclimatic envelope of the wolverine Gulo gulo: do climatic constraints limit its geographic distribution? Canadian Journal of Zoology 88: 233-246. https://doi.org/10.1139/Z09-136

Dawson, N.F., A.J. Magoun, J. Bowman, and J.C. Ray. 2010. Wolverine, Gulo gulo, home range size and denning habitat in lowland boreal forest in Ontario. Canadian Field-Naturalist 124: 139-144. https://doi.org/10. 22621/cfn.v124i2.1052

Fuller, T.K., and L.B. Keith. 1980. Summer ranges, cover type use and denning of black bears Ursus americanus near Fort McMurray, Alberta, Canada. Canadian FieldNaturalist 94: 80-83. Accessed 1 February 2018. https:/ biodiversitylibrary.org/page/28088961.

Gigliotti, L.C., B.C. Jones, M.J. Lovallo, and D.R. Diefenbach. 2018. Snowshoe hare multi-level habitat use in a fire-adapted ecosystem. Journal of Wildlife Management 82: 435-444. https://doi.org/10.1002/jwmg. 21375

Gilbert, J.H., J.L. Wright, D.J. Lauten, and J.R. Probst. 1997. Den and rest-site characteristics of American Marten and Fisher in northern Wisconsin. Pages 135145 in Martes: Taxonomy, Ecology, Techniques, and Management. Edited by G. Proulx, H.N. Bryant, and P.M. Woodard. The University of Alberta Press. Edmonton, Alberta, Canada.

Hodges, K.E. 2000. The ecology of Snowshoe Hares in northern boreal forests. Pages 117-161 in Ecology and Conservation of Lynx in the United States. Edited by L.F. Ruggiero, K.B. Aubry, S.W. Buskirk, G.M. Koehler, C.J. Krebs, K.S. McKelvey, and J.R. Squires. Department of Agriculture, Forest Service, Rocky Mountain Research Station. Fort Collins, Colorado, USA.

Inman, R.M., A.J. Magoun, J. Persson, and J. Mattisson. 2012. The wolverine's niche: linking reproductive chronology, caching, competition, and climate. Journal of Mammalogy 93: 634-644. https://doi.org/10.1644/ 11-mamm-a-319.1

Kimmerer, R.W. 2003. Gathering Moss. Oregon State University Press, Corvallis, Oregon, USA.

Klenner, W. 1982. Seasonal movements, home range utilization, and denning habits of black bears (Ursus americanus) in western Manitoba. M.Sc. thesis, University of Manitoba, Winnipeg, Manitoba, Canada.

Klenner, W., and D.W. Kroeker. 1990. Denning behavior of black bears Ursus americanus, in western Manitoba. Canadian Field-Naturalist 104: 540-544. Accessed 1 February 2018. https://biodiversitylibrary. org/page/34347100.

Kolenosky, G.B., and S.M. Strathearn. 1987. Winter denning of Black Bears in east-central Ontario. Bears: their biology and management. Pages 305-316 in Papers from the Seventh International Conference on Bear Research and Management, Plitvice Lakes, Yugoslavia.

Krebs, C.J., R. Boonstra, and S. Boutin. 2018. Using experimentation to understand the 10 -year snowshoe hare cycle in the boreal forest of North America. Journal of Animal Ecology 87: 87-100. https://doi.org/10.1111/13

\section{5-2656.12720}

Krebs, J.A., and D. Lewis. 2000. Wolverine ecology and habitat use in the North Columbia Mountains: progress report. Pages 695-703 in Proceedings of Biology and Management of Species and Habitats at Risk. Edited by L.M. Darling. University College of the Cariboo, Kamloops, British Columbia, Canada.

Krebs, J.A., E.C. Lofroth, and I. Parfitt. 2007. Multiscale habitat use by wolverines in British Columbia, Canada. Journal of Wildlife Management 71: 2180-2192. https:// doi.org/10.2193/2007-099

May, R., L. Gorini, J. van Dijk, H. Brøseth, J.D.C. Linnell, and A. Landa. 2012. Habitat characteristics associated with wolverine den sites in Norwegian multiple-use landscapes. Journal of Zoology 287: 195-204. https://doi.org/10.1111/j.1469-7998.2012.00907.x

Magoun, A.J., and J.P. Copeland. 1998. Characteristics of wolverine reproductive den sites. Journal of Wildlife Management 62: 1313-1320. https://doi.org/10.2307/380 1996

Magoun, A.J., C.D. Long, M.K. Schwartz, K.L. Pilgrim, R.E. Lowell, and P. Valkenburg. 2011. Integrating motion-detection cameras and hair snags for wolverine identification. Journal of Wildlife Management 75: 731739. https://doi.org/10.1002/jwmg.107

Magoun, A.J., M.D. Robards, M.L. Packila, and T.W. Glass. 2017. Detecting snow at the den-site scale in wolverine denning habitat. Wildlife Society Bulletin 41: 381-387. https://doi.org/10.1002/wsb.765

Makkonen, T. 2015. Den site characteristics of female wolverine (Gulo gulo) in Scandinavian forested landscape. M.Sc. thesis, University of Oulu, Oulo, Sweden.

Marchand, P.J. 2014. Life in the Cold: an Introduction to Winter Ecology. Fourth Edition. University Press of New England, Hanover, New Hampshire, USA.

Moldowan, P.D., and H. Kitching. 2016. Observation of an Eastern Wolf (Canis sp. cf. Lycaon) caching food in a Sphagnum bog in Algonquin Provincial Park, Ontario. Canadian Field-Naturalist 130: 351-354. https://doi.org/ 10.22621/cfn.v130i4.1930

Natural Regions Committee. 2006. Natural regions and subregions of Alberta. Compiled by D.J. Downing and W.W. Pettapiece. Government of Alberta. Pub. No. T/852. Accessed 1 January 2018. https://open.alberta.ca/ publications/0778545725.

Persson, J. 2005. Female wolverine (Gulo gulo) reproduction: reproductive costs and winter food availability. Canadian Journal of Zoology 83: 1453-1459. http:// dx.doi.org/10.1139/z05-143

Pulliainen, E. 1968. Breeding biology of the wolverine (Gulo gulo) in Finland. Annales Zoologici Fennici 5: 338-344.

Ruggiero, L.F., E. Pearson, and S.E. Henry. 1998. Characteristics of American marten densites in Wyoming. Journal of Wildlife Management 62: 663-673. https://doi.org/10.2307/3802342

Scrafford, M.A., T. Avgar, R. Heeres, and M.S. Boyce. 2018. Roads elicit negative movement and habitatselection responses by wolverines (Gulo gulo luscus). Behavioral Ecology 29: 534-542. https://doi.org/10.1093 /beheco/arx182 
Scrafford, M.A., and M.S. Boyce. 2015. Effects of industrial development on wolverine (Gulo gulo) ecology in the boreal forest of northern Alberta. Wolverine Project Progress Report - Winter 2014/2015. Accessed 1 February 2018. http://wolverinefoundation.org/wpcontent/uploads/2011/02/Scrafford-and-Boyce_2015 Wolverine-Project-Progress-Report.pdf.

Soudzilovskaia, N., P. Bodegom, and J. Cornelissen. 2013. Dominant bryophyte control over high-latitude soil temperature fluctuations predicted by heat transfer traits, field moisture regime and laws of thermal insulation. Functional Ecology 27: 1442-1454. https://oi.org/ 10.1111/1365-2435.12127

Stelfox, J.B. 1995. Relationships between stand age, stand structure, and biodiversity in aspen mixedwood forests in Alberta. Jointly published by Alberta Environmental Centre (AECV95-R1), Vegreville, Alberta, and Canadian Forest Service (Project No. 0001A), Edmonton, Alberta, Canada. Accessed 1 February 2018. http://cfs. nrcan.gc.ca/pubwarehouse/pdfs/19534.pdf.

Tietje, W.D., and R.L. Ruff. 1980. Denning behavior of black bears in boreal forest of Alberta. Journal of Wildlife Management 44: 858-870. https://doi.org/10.2307/ 3808314

Verhoeven, J.T.A., and W.M. Liefveld. 1997. The ecological significance of organochemical compounds in
Sphagnum. Acta Botanica Neerlandica 46: 117-130.

Webb, S.M., R.B. Anderson, D.L. Manzer, B. Abercrombie, B. Bildson, M.A. Scrafford, and M.S. Boyce. 2016. Distribution of female wolverines relative to snow cover, Alberta, Canada. Journal of Wildlife Management 80: 1461-1470. https://doi.org/10.1002/jwmg. 21137

Webb, S., D. Manzer, R. Anderson, and M. Jokinen. 2013. Wolverine harvest summary from registered traplines in Alberta, 1985-2011. Technical Report, T-2013001, produced by the Alberta Conservation Association, Sherwood Park, Alberta, Canada. Accessed 11 January 2019. https://www.ab-conservation.com/downloads/ report_series/wolverine_harvest_in_alberta_1985-2011. pdf.

Wood, M.D., and E.L. Terry. 1999. Seasonal movements and habitat selection by Woodland Caribou in the Omineca Mountains, north-central British Columbia Phase 1: The Chase and Wolverine Herds (1991-1994). Peace/ Williston Fish and Wildlife Compensation Program, Report No. 201. Prince George, British Columbia, Canada. Accessed 1 March 2019. http://www.env.gov. bc.ca/wildlife/wsi/reports/4737_WSI_4737_RPT_ OMINECA_1991_1994.PDF.

Received 31 July 2018

Accepted 28 February 2019 